\title{
BREEDS, AGE AND SEX EFFECT ON HAEMATOLOGICAL AND BIOCHEMICAL PARAMETERS OF DUCKS IN RIVERS STATE, NIGERIA
}

\author{
Festus OLOGBOSE ${ }^{1 *}$, Samuel DICK ${ }^{1}$ \\ ${ }^{1}$ Department of Animal Science, University of Port Harcourt, Rivers State, Nigeria
}

\begin{abstract}
This study was carried out to investigate breeds, age and sex effect on haematological and biochemical profiles of ducks. A total of one hundred and twenty (120) day old ducklings of two breeds (60 Muscovy and 60 Mallards) were used for the study. The ducks were divided into four (4) groups centered on the breeds and sexes designated as Muscovy males, Muscovy females, Mallard males and Mallard females. At 4 and 8 weeks, blood samples were collected from the experimental group and analysed. The experiment was $2 \times 2 \times 2$ factorial in a Randomized Complete Block Design with two breeds (Mallard and Muscovy), sex and age. Results obtained showed significant effect $(\mathrm{P}<0.05)$ of breeds on Packed Cell Volume, Haemoglobin, Red Blood Cells (RBC), White Blood Cells, Platelets, Total Proteins, Albumin, Globulin and Tryglycerides while no significant effect of breeds $(\mathrm{P}>0.05)$ was observed on Urea, Creatinine and Glucose in the two breeds of ducks. Result indicated that Muscovy recorded higher values for Haemoglobin $(10.35 \pm 0.52 \mathrm{~g} / \mathrm{dl})$ and RBC $(4.62 \pm 0.24 \times 1012 / \mathrm{L})$ than Mallard which recorded Haemoglobin $(10.10 \pm 0.62 \mathrm{~g} / \mathrm{dl})$ and RBC $(4.43 \pm$ $0.27 \times 1012 / \mathrm{L})$. Significant effects of Sex and age $(\mathrm{P}<0.05)$ were observed on haematological and biochemical profiles. It is therefore concluded that the two breeds of ducks studied can be successfully raised in Rivers State, Nigeria without adverse effect on their health since their haematological and biochemical values compared favorably with standard reference values. Values obtained in this investigation could also serve as a baseline data of these breeds in humid tropical environment.
\end{abstract}

Keywords: Age, Duck breeds, Sex, Haematological and Biochemical parameters

*Corresponding author: Department of Animal Science, University of Port Harcourt, Rivers State, Nigeria
E mail: drovharhe.oghenero@gmail.com (F. OLOGBOSE)
$\begin{array}{ll}\text { Festus OLOGBOSE } & \text { (D) https://orcid.org/0000-0003-1611-4355 } \\ \text { Samuel DICK } & \text { (D) https://orcid.org/0000-0003-0979-6423 }\end{array}$

Received: June 26, 2020

Accepted: December 27, 2020

Published: April 01, 2021

Cite as: Ologbose F, Dick S. 2021. Breeds, age and sex effect on haematological and biochemical parameters of ducks in rivers state, Nigeria. BSJ Agri, 4(2): 52-57.

\section{Introduction}

Farmers as well as Animal scientists are observing different varieties of domesticated ducks which have suitable potential to grow fast and supplement the availability of meat on economic basis. Under this situation, duck industry has been gaining impulse in Rivers State, Nigeria, as well as providing all essential substances as in comparatively low percentage of fat and high percentage of protein. Therefore, haematology denotes the study of the quantities and morphology of the cellular components of the blood- the red cells (erythrocytes), white cells (leucocytes), platelet and the usage of these results in the diagnosis and observing of disease (Merck Manual, 2012).

Biochemical refers to the study of chemical processes within and relating to living organism. Haematological and biochemical tests have not widely been useful for diagnosis of avian species, but these tests could be an appropriate diagnosis mechanism for monitoring health status or for following of sickness ducks responses to therapeutic regimes, and giving a prognosis to some duck diseases. In animal health, blood analyses have been performed much less often in avian in contrast to its predictable use in mammalian species (Oladele, 2001). Haematological and biochemical profiles will help to screen the blood profiles in order to discover the health position of the animals. For animal to be certified healthy, its blood profile has to meet certain standards. Haematological and serum biochemical profiles offer dependable information on the health status of animals (Cetin et al., 2009). They also reveal the sensitivity of an animal to its internal and external environments treatment (Esonu et al., 2001).

The blood profile could be influenced by sex, age, genetic makeup, climatic factors and management practice among others (Oladele et al., 2000). By establishing the haematological and biochemical values of Mallard and Muscovy at different ages and sexes, valuable indices will be obtained for assessing their health status. The indices may also be used as biomarkers for selection and improvement purposes. This research will also help to provide baseline information on haematological and biochemical parameters for breed identification on mallard and Muscovy breed of duck in the humid tropic environment. The objective of this study was to 


\section{Black Sea Journal of Agriculture}

determine the effect of breeds, age and sex on haematological and biochemical parameters of ducks.

\section{Material and Methods}

A total of 120 day old ducklings (i.e. 60 Muscovy and 60 Mallard) were used for the study. Each breed consists of 30 males and 30 females which were replicated into three. The ducks were given routine vaccination during the period of the experiment. Lasota and Gomboro vaccines were administered to the ducks periodically at 7 days and 14 days via drinking water. Commercial feed was provided in adequate quantity to the ducks twice a day, drinking water was given adlibitum. The ducks (04weeks) were fed ad libitum with starter mash containing $21-22 \%$ crude protein and 2,850 - 2,900kcal $\mathrm{ME} / \mathrm{kg}$ and finishers (5-8weeks) were fed 19\% crude protein and $3000 \mathrm{kcal} \mathrm{ME} / \mathrm{kg}$. Individual identification of the ducks was done by marking wing banding. The experimental animals were kept in a confined pen under intensive system at ambient temperature of $32^{\circ} \mathrm{c}-37^{\circ} \mathrm{c}$ with relative humidity of $68-74 \%$. The experimental animals were sexed using their body weight and present of bright red and larger combs for separating males from females.

A total of 120 blood samples were collected from two breeds of ducks (i.e. 60 from Muscovy and 60 Mallards) at 4 and 8 weeks and these were used to determine haematological and biochemical studies based on breeds, age and sex. Blood samples $(2.5 \mathrm{ml})$ were collected aseptically with sterile syringe and needles from the wing vein of the different breeds of duck into labeled bottles without anti-coagulant to allow for clotting in serum biochemical and samples for hematological studies was collected in bottles treated with ethylene di amine tetra-acetic acid (EDTA) done immediately after the wing had being damped with methylated spirit to disinfect the area and expose the vein. Determination was done based on sex of the ducks for packed cell volume (PCV), Hemoglobin (Hb), white blood cells (WBC), RBC, platelet, total protein, albumin, urea, creatinine, glucose, globulin and triglyceride. Evaluation was conducted according to the methods already described by Ahemen, et al (2015).

\subsection{Statistical Analysis}

The experiment was designed as a $2 \times 2 \times 2$ factorial in a Randomized Complete Block Design (RCBD). Duncan's multiple range test (Duncan, 1955) was used to compare means of the two breeds, age and their sexes. Data obtained were statistically analysed with SPSS (2011) package version 20. The statistical model (equation 1) is as follows;

$Y_{i j k 1}=\mu+B_{i}+S_{J}+A_{K}+B S A_{i j K}+e_{i j k L}$

$Y_{i j k 1}=$ Single observation on the $\mathrm{i}^{\text {th }}$ breed,

$\mu=$ Population mean,

$B_{i}=$ effect of $\mathrm{i}^{\text {th }}$ breed,

$S_{J}=$ effect of Jth $^{\text {th }}$,

$A_{K}=$ Effect of $\mathrm{k}^{\text {th }}$ Age,

$B S A_{i j K}=$ Effect of interaction among the breeds, age and sex,

$e_{i j k}=$ random error, which is assumed to be identically and independently distributed with zero, error and constant variance.

\subsection{Ethical Consideration}

The research was approved by the University of Port Harcourt research ethics committee for care and use of animals for research.

\section{Results and Discussion}

Table 1 showed breeds effect on Haematological and biochemical parameters of Muscovy and Mallard Breeds of Duck. The results showed that significant effects $(\mathrm{P}<$ 0.05 ) of breeds were observed in all the hematological and biochemical profiles of ducks.

Table 1. Mean + standard error effect of breeds of ducks on haematological and biochemical parameters

\begin{tabular}{lccc}
\hline Blood Parameters & Muscovy & Mallard & Reference values \\
\hline Packed Cell Volume (\%) & $31.00 \pm 1.56^{\mathrm{b}}$ & $31.167 \pm 1.26^{\mathrm{a}}$ & $22 \pm 40$ \\
Hemoglobin (g/dl) & $10.35 \pm 0.52^{\mathrm{a}}$ & $10.10 \pm 0.62^{\mathrm{b}}$ & $8 \pm 12$ \\
Red Blood Cell (x1012/L) & $4.62 \pm 0.24^{\mathrm{a}}$ & $4.43 \pm 0.27^{\mathrm{b}}$ & $2.85 \pm 5.63$ \\
White Blood Cell (x109/L) & $12.21 \pm .7 .17^{\mathrm{b}}$ & $12.31 \pm 0.91^{\mathrm{a}}$ & $10.4 \pm 15.2$ \\
Platelet(x109/L) & $249.41 \pm 4.91^{\mathrm{b}}$ & $257.91 \pm 7.91^{\mathrm{a}}$ & $209 \pm 314$ \\
Total protein (g/l) & $48.41 \pm 1.44^{\mathrm{b}}$ & $53.41 \pm 1.04^{\mathrm{a}}$ & $40 \pm 75$ \\
Albumin (g/l) & $25.66 \pm 1.44^{\mathrm{b}}$ & $30.00 \pm 0.84^{\mathrm{a}}$ & $25 \pm 28$ \\
Urea (mol/l) & $2.78 \pm 0.19^{\mathrm{b}}$ & $3.29 \pm 0.42^{\mathrm{a}}$ & $2 \pm 5.74$ \\
Creatinine(mol/l) & $130.75 \pm 3.77^{\mathrm{b}}$ & $141.16 \pm 3.27^{\mathrm{a}}$ & $92 \pm 141$ \\
Glucose (mol/l) & $5.87 \pm 0.50^{\mathrm{b}}$ & $6.61 \pm 0.35^{\mathrm{a}}$ & $3.8 \pm 7.2$ \\
Globulin (g/l) & $21.91 \pm 1.40^{\mathrm{b}}$ & $23.41 \pm 1.22^{\mathrm{a}}$ & $20 \pm 45$ \\
Triglyceride (g/l) & $1.42 \pm 0.09^{\mathrm{b}}$ & $1.62 \pm 0.07^{\mathrm{a}}$ & $1.20 \pm 4$ \\
\hline
\end{tabular}

a,bMeans within the same row with different superscript differ significantly $(\mathrm{P}<0.05)$.

The results revealed that Muscovy had higher values in $\mathrm{Hb}$ and RBC than Mallard breed of duck. While, Mallard recorded higher values in PCV, WBC and Platelets (PLT),
Total Protein (TP), Albumin (ALB), Urea (UR),Creatinine (CRT), Glucose (GLU) Globulin (GLO) and Triglyceride (TRG). The results also indicated that Mu recorded higher 
values for $\mathrm{Hb}(10.35 \pm 0.52 \mathrm{~g} / \mathrm{dl})$ and $\mathrm{RBC}(4.62 \pm 0.24 \times$ $\left.10^{12} / \mathrm{L}\right)$ than Ma which recorded $\mathrm{Hb}(10.10 \pm 0.62 \mathrm{~g} / \mathrm{dl})$ and $\mathrm{RBC}\left(4.43 \pm 0.27 \times 10^{12} / \mathrm{L}\right)$. The significant difference $(\mathrm{P}<0.05)$ of breeds on haematological and biochemical profiles observed in Table 1, this study may be in response to differences in adaptations of these improved breeds of ducks as there are overlaps between the different adaptation in animals to meet the requirements of their given environment (Horton, 2005). According to these authors, animal populations are genetically modified in response to environmental challenge to shape their unique characteristics in an adaptive manner. The result also revealed that mallard recorded higher value of WBC and PCV. Thus may indicate its higher immunity status against diseases where the lower WBC value of the Muscovy may indicate its lower status. Animals with lower WBC are exposed to high risk of disease infection while those with high counts are capable of generating antibodies in the process of phagocytocis and have high degree of resistance to disease (Soetan et al., 2013) and enhanced adaptability to local environmental and disease prevalent condition (Kabir et al., 2011) the result obtained was similar to that of (Soetan et al., 2013) where they also observed similar significant $(\mathrm{P}<0.05)$ different in haematological and biochemical indices. The high values reordered for mallard in PCV shows that this breed has better blood status. Increase PCV of the mallard shows a better transportation and thus result in an increased primary and secondary polycythemia.

Table 2 shows effect of sex on haematology and biochemical of Muscovy and Mallard breeds of duck. The results shows that significant $(\mathrm{P}<0.05)$ effect of sex was observed in all the hematological and biochemical profiles studied except in ALB. The results also revealed that the female Mu had higher values in PCV, Hb, RBC, TP, UR, CRT, GLU and GLO than the male counterpart. While, the male Muscovy had higher values in WBC, PLT and TRG than the females. It was also revealed that no significant effect of sex was observed $(\mathrm{P}>0.05)$ on Glucose (6.56 mol/l) male, Glucose (6.66 mol/l) female; triglyceride $(1.77 \mathrm{~g} / \mathrm{l})$ male, Triglyceride $(1.47 \mathrm{~g} / \mathrm{l})$ female Mallard duck. The results also revealed that sex effect on male mallard on hematological and biochemical parameters were higher in values of PCV, WBC, PLTL, TP, $\mathrm{Hb}, \mathrm{UR}, \mathrm{CRT}$, GLO, TRG than that of female mallard while the (hemoglobin, red blood cell, Glucose) of the female Mallard are higher compared to the male breed.

Table 2 revealed that significant effects of sex $(\mathrm{P}<0.05)$ were observed on haematological and biochemical profiles of Muscovy and Mallard breeds of duck in this study. This result was in line with the findings of (Yaqub et al, 2013) where they observed significant effect of sex on haematological and biochemical parameters of farm animals but contrary to the findings of Olayemi et al. (2006) where they observed no significant in sex difference in PCV, RBC and WBC.

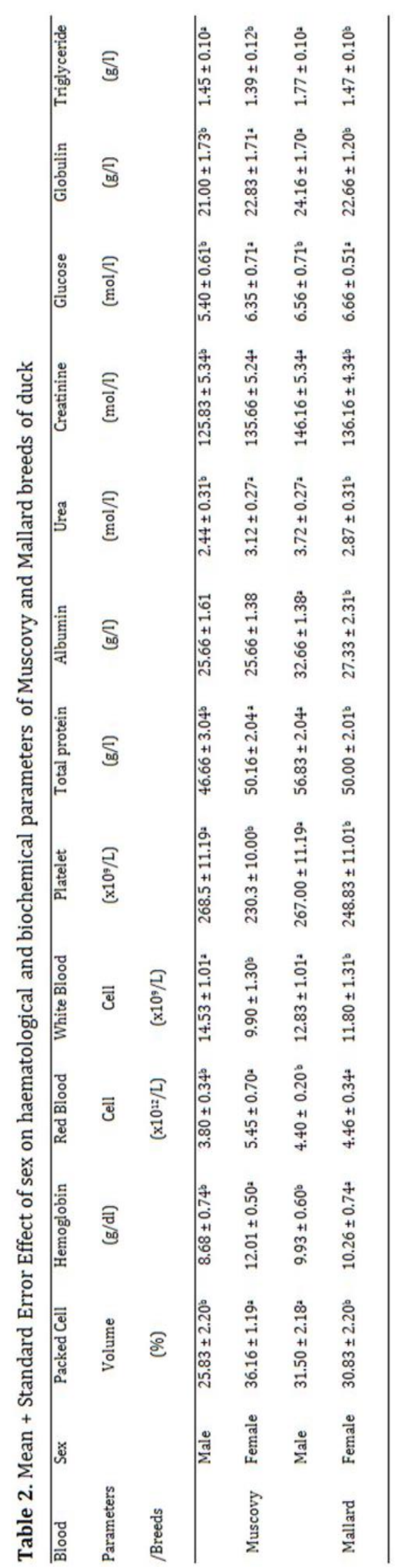




\section{Black Sea Journal of Agriculture}

According to Oladele et al. (2001), the male ducks recorded higher haematological values than female ducks. This is in line with the findings of this study where male mallard recorded higher haemotological and biochemical value than that of female mallard. The mean haemoglobin values which were higher in in male ducks than in females are involved in maintaining haemostasis as they help to preserve vascular integrity (Olayemi et al., 2006). The effect of sex on plasma proteins has been shown to vary in birds, depending on the breed of the birds. Significantly higher total protein level had been reported in the females than in male guinea fowls (Oladele et al., 2005) and chickens (Oladele et al., 2000). However, no significant sex variation in total protein was observed in local ducks (Oladele et al., 2001) The rise in blood parameters in male in compare with females is often attribute to the effects of androgens, which stimulates enthropoiesis and the cause increase in the number of circulating RBC, PCV and HB concentration (Villier and Dunn, 1998). The result obtained also fall within the reference values of haematological and biochemical profile of ducks (Rajashree, 2017). The discrepancies observed between haematological and biochemical parameters in this investigation as influenced by sex may be owed to inherent sex differences among male and female breeds of duck. While, the variations observed in this study and those reported by other authors could be due to differences in breeds, species, age, climate, season, blood collection procedures, animal housing, nutrition and subclinical illness.

Table 3 shows effect of age on haematology and biochemical parameter of Muscovy and Mallard breeds of duck. The result revealed significant $(\mathrm{P}<0.05)$ age effect on haematological and biochemical profiles of Muscovy and Mallard breeds of duck at 4 and 8 weeks. The results showed that Muscovy had higher values of haematological and biochemical values at 4 weeks in PCV $(34.66 \pm 2.22 \%)$, Hb $(11.50 \pm 60 \%)$, RBC $(5.11 \pm 0.20$ $\left.\mathrm{x} 10^{12} / \mathrm{L}\right)$, PLTL, TP, ALB, UR, CRT, GLU, GLO and TRG than at 8 weeks. This showed that the mentioned parameters decreased with age. While, WBC, TP, ALB and GLO recorded higher values at week 8 in Muscovy ducks, this indicates that the mentioned blood profiles increased with age. The result also showed that Mallard duck recorded higher values of haematological and biochemical parameters in RBC, Hb, PCV, PLT, URE, CRT, GLU and TRG at age 4 weeks than at 8 weeks, this also showed that the mentioned blood profiles decreased with age. While, Mallard ducks recorded higher values in WBC, TP, ALB and GLO at 8 weeks than at 4 weeks, this indicates that the mentioned blood profiles increased with age.

Table 3. Mean + standard error effect of age on haematology and biochemical parameters of Muscovy and Mallard breed of ducks

\begin{tabular}{lcccc}
\hline \multirow{2}{*}{ Blood Parameters } & \multicolumn{2}{c}{ Muscovy } & \multicolumn{2}{c}{ Mallard } \\
\cline { 2 - 4 } Packed Cell Volume (\%) & 4 weeks & 8 weeks & 4 weeks & 8 weeks \\
Hemoglobin (g/dl) & $34.66 \pm 2.22^{\mathrm{a}}$ & $27.33 \pm 2.20^{\mathrm{b}}$ & $32.33 \pm 2.23^{\mathrm{a}}$ & $30.00 \pm 2.20^{\mathrm{b}}$ \\
Red Blood Cell (x1012/L) & $11.50+0.60^{\mathrm{b}}$ & $9.20 \pm 0.74^{\mathrm{a}}$ & $10.20 \pm 0.94^{\mathrm{a}}$ & $10.00 \pm .74 \mathrm{~b}$ \\
White Blood Cell (x109/L) & $5.11 \pm 0.20^{\mathrm{b}}$ & $4.13 \pm 0.74^{\mathrm{a}}$ & $4.56 \pm 0.61^{\mathrm{a}}$ & $4.30 \pm 0.34^{\mathrm{b}}$ \\
Platelet(x109/L) & $9.41 \pm 1.01^{\mathrm{a}}$ & $15.01 \pm 1.13^{\mathrm{b}}$ & $11.61 \pm 1.00^{\mathrm{a}}$ & $13.01 \pm 1.01^{\mathrm{b}}$ \\
Total protein (g/l) & $251.66 \pm 11.19^{\mathrm{a}}$ & $247.16 \pm 10.19^{\mathrm{b}}$ & $267.00 \pm 11.13^{\mathrm{a}}$ & $248.83 \pm 11.10^{\mathrm{b}}$ \\
Albumin (g/l) & $42.16 \pm 2.04^{\mathrm{a}}$ & $54.66 \pm 1.04^{\mathrm{b}}$ & $42.50 \pm 2.07^{\mathrm{b}}$ & $64.33 \pm 2.04 \mathrm{a}^{\mathrm{a}}$ \\
Urea (mol/l) & $24.33 \pm 1.38^{\mathrm{a}}$ & $27.00 \pm 1.26^{\mathrm{b}}$ & $25.50 \pm 1.41^{\mathrm{b}}$ & $34.50 \pm 1.388^{\mathrm{a}}$ \\
Creatinine(mol/l) & $3.32 \pm 0.27^{\mathrm{a}}$ & $2.24 \pm 0.30^{\mathrm{b}}$ & $4.02 \pm 0.13^{\mathrm{a}}$ & $2.57 \pm 0.27^{\mathrm{b}}$ \\
Glucose (mol/l) & $138.33 \pm 4.34^{\mathrm{a}}$ & $123.16 \pm 5.344^{\mathrm{b}}$ & $153.00 \pm 5.61^{\mathrm{a}}$ & $129.33 \pm 5.34^{\mathrm{b}}$ \\
Globulin (g/l) & $7.36 \pm 0.61^{\mathrm{b}}$ & $4.38 \pm 0.71^{\mathrm{a}}$ & $7.70 \pm 0.91^{\mathrm{a}}$ & $5.53 \pm 0.71^{\mathrm{b}}$ \\
Triglyceride (g/l) & $17.83 \pm 1.71^{\mathrm{a}}$ & $26.00 \pm 1.73^{\mathrm{b}}$ & $17.00 \pm 1.62^{\mathrm{b}}$ & $29.83 \pm 1.73^{\mathrm{a}}$ \\
\hline
\end{tabular}

a,b Means within the same row with different superscript differ significantly $(\mathrm{P}<0.05)$.

According to Olayemi et al. (2003); PCV, HB and RBC indices were similar in young and adult animals. This was contrary to the finding of Kral and Suchy (2000) where haematological profile of domestic animals more in young animals than older animals but in this study, since haematological and biochemical profile where higher at week 4 than week 8, it was in agreement with the findings of Devi and Kumar (2012) where they observed increase in haematological values in growing animals as compared to adults which is apparently due to high basal metabolic rates.

Olayemi et al. (2006) reported that concentration of Total Protein in serum of ducks showed significant $(\mathrm{P}<0.05)$ growth with ageing which is also in accord with the finding of this study. Talebi et al. (2005) showed that age effect significant $(\mathrm{P}<0.05)$ the haematological profile of 


\section{Black Sea Journal of Agriculture}

ducks at 8 weeks which is also steady with the significant influence of age observed in this study. Hemandez et al. (2008) revealed an age dependent gradual decline in Total Protein concentration which is consistent with this study. Olayemi et al. (2006) also reported significant differences in Total Protein among difference ages in ducks which is in agreement with the present findings. The reduction in blood glucose in the two breeds of ducks observed in this study may implies that the ducks metabolic function may be hampered since glucose provides energy production through cellular oxidation, glycogen synthesis in liver and glycolytic muscles, fatty acid synthesis as well as synthesis of nonessential amino acid, vitamin $\mathrm{C}$ and other metabolites (Hemandez et al., 2008). The decline in the blood glucose may again depend on the balance between the intake of carbohydrates and the endogenous glucose synthesis and release by the liver on one hand and storage, utilization and excretion on the other hand. WBC is higher with age in Muscovy; this gives the impression of a better resistance and survival as the age.

\section{Conclusion}

The two breeds of duck (Muscovy and Mallard) examined have some differences in respect to breeds, age and sex on blood parameters indicating that the two duck breeds are not similar to each other. Significant main effect was observed in PCV, Hb, RBC, WBC, Total Protein, ALB, GLO and TRG which suggest genetic dissimilarities. Nonsignificance was observed in urea, creatinine and glucose which suggested genetic similarity among them. The similarity and differences obtained between the two breeds should be subjected to further analysis; however, the haematological and biochemical parameters variation in this study might also be due to gene in breed of ducks used. This will aid in planning breeding programme for selection of economic traits. The heamatological and biochemical values obtained in this study could serve as a baseline data of these breeds of duck in Rivers state, Nigeria. The results from this study fill an important gap in the literature by providing reference intervals for hematology and biochemistry parameters in breeds of ducks for commercial purposes. The breeds selected appeared to be in good health and the ducks chosen lacked clinical signs or physical abnormalities on physical examination, thus the variation in parameters may reflect what is expected in Rivers State, Nigerian commercial ducks. It is important to continue to assess and publish hematological and biochemical blood parameters for these animals, as well as for other stages of production, to aid veterinarians and researchers in the identification of clinical or subclinical disease or metabolic and nutritional problems. Haematological and biochemical parameters of ducks are significantly influenced by breeds, sex and age. These factors should be considered when interpreting the parameters in order to ensure accuracy.

\section{Author Contributions}

FO designed the study, supervised the research, carried out the statistical analysis and wrote the first manuscript. DS carried out the field work. Both authors read, corrected and approved the final manuscript.

\section{Conflict of Interest}

The authors declare that there is no conflict of interest.

\section{References}

Ahemen T, Bitto II, Oluremi OIA, Anugwa FOI. 2015. Genital tract morphometric and haematological of male rabbits fed graded levels of cassava leaf meal. Nigerian J Anim Prod, 42: 50-59.

Cetin N, Bekyurek T, Cetin E. 2009. Effects of sex, pregnancy and season on some haematological and biochemical blood values in Angora Rabbits. Scand J Lab Anim Sci, 36: 155-162.

Devi R, Kumar MP. 2012. Effect of ageing and sex on the ceruloplasmin (Cp) and the plasma protein levels. J Clin Diagno Res, 6(4): 577-580.

Duncan DB. 1955. Multiple range and multiple $\mathrm{F}$ tests. Biometrics, 11: 1-42.

Esonu BO, Emenalom 0O, Udedebie U, Herbert DF, Ekpori IC, Iheukwuemere FC. 2001. Performance and blood chemistry of weaner pigs fed raw mucuna bean (velvet bean) meal. Trop Anim Prod Invest, 4: 49-54.

Hernandez AM, Satue K, Lorente C, Garces C, Oçonnor JE. 2008. The influence of age and gender on haematologic parameters in Spanish Horses. In: Proceedings of Veterinary European Equine Meeting, Jan 25-27, Venice, Italy.

Horton TH. 2005. Fetal origins of developmental plasticity: Animal models of induced life history variation. Am J Human Biol, 17(1): 34-43.

Merck Manual. 2012. Haematologic reference ranges. Mareck Vet Manual, http://www.merckmanuals.com/ (accessed date: March 23, 2012).

Oladele SB, Ayo JO, Esievo KAN, Ogundipe SO. 2000. Effect of season and sex on packed cell volume, haemoglobin and total protein of indigenous chickens in Zaria, Nigeria. J Med Allied Sci, 3: 173-177.

Oladele SB, Ayo JO, Esievo KAN, Ogundipe SO. 2001. Seasonal and sex variations in packed cell volume, haemoglobin and total protein of indigenous duck in Zaria, Nigeria. J Trop Biosci, 1(1): 84-88.

Oladele SB, Ayo JO, Ogundipe SO, Esievo KAN. 2005. Seasonal and sex variations in packed cell volume, haemoglobin and total protein of the guinea fowl (Numida meleagris) in Zaria, Northern Guinea Savannah zone of Nigeria. J Trop Biosci, 5(2): 67-71.

Olayemi FO, Oyewale JO, Omolewa OF. 2002. Plasma chemistry values in the young and adult Nigerian duck (Anas platyrhynchos). Israel J Vet Med, 57: 1-5.

Olayemi F, Oyewale J, Rahman S, Omolewa 0. 2003. Comparative assessment of the white blood cell values, plasma volume and blood volume in the young and adult Nigerian duck (Anas platyrhynchos). Vet Archiv, 73(5): 27-276.

Olayemi FO, Ojo EO, Fagbohun OA. 2006. Haematological and plasma biochemical parameters of the Nigerian laughing dove (Streptopelia senegalensis) and the Nigerian duck (Anas platyrhynchos). Vet Archiv, 76 (2): 145-151.

Kabir M, Akpa GN, Nwagu BI, Adeyinka IA, Bello UI. 2011. Sexual dimorphism, breed and age characteristics of rabbits in Zaria, Nigeria. In Proceedings of the 16th Annual Conference of Animal Science Association, Nigeria, p.133-137. 


\section{Black Sea Journal of Agriculture}

Kral I, Suchy P. 2000. Haematological studies in adolescent breeding cocks. Acta Vet Brno, 69: 189 - 194.

Rajashree R, Bhajirathi P, Mishra SK. 2017. Comparative serum biochemical profile for different breeds of ducks versus white leghorn chickens in peak laying period. Indian J Anim Res, 53(3): 327-331.

Soetan KO, Akinrinde AS, Ajibade TO. 2013. Preliminary studies on the haematological parameters of cockerels fed raw and processed guinea corn (Sorghum bicolor). In Proceedings of 38th Annual Conference of Nigerian Society for Animal Production, Nigeria, pp. 49-52.
Talebi A, Asri-Rezaei S, Rozeb-Chai R, Sahraei R. 2005. Comparative studies on Haematological values of Broilers Strain (Ross, Cobb, Arbor -acres and Arian) Inter J Poultry Sci, 4: 573-579.

Villiers E, Dunn JK. 1998. Basic haematology. In: Davidson M, Else Rand Lumsden, J. editors. Manual of small animal clinical pathology, Shurdngton, Cheltenham, United Kingdom, pp. 3360.

Yaqub LS, Kawu MU, Ayo J0. 2013. Influence of reproductive cycle, sex, age, and season on haemtologic parameters in domestic Animals: A review. J Cell Anim Biol, 7(4): 37-43. 